\title{
Single and Sequential Extraction of Copper by Different Extractants from Different Peat Soil Samples of Bangladesh
}

\author{
Ishrat Jahan Sanchary ${ }^{*}$, Tania Akter² \\ ${ }^{1}$ Department of Soil and Environmental Sciences, University of Barishal, Barishal, Bangladesh \\ ${ }^{2}$ Department of Soil, Water and Environment, University of Dhaka, Dhaka, Bangladesh \\ Email: ^ijsanchary@gmail.com
}

How to cite this paper: Sanchary, I.J. and Akter, T. (2021) Single and Sequential Extraction of Copper by Different Extractants from Different Peat Soil Samples of Bangladesh. Open Journal of Soil Science, 11, 611-627.

https://doi.org/10.4236/ojss.2021.1112030

Received: November 30, 2021

Accepted: December 27, 2021

Published: December 30, 2021

Copyright $\odot 2021$ by author(s) and Scientific Research Publishing Inc. This work is licensed under the Creative Commons Attribution International License (CC BY 4.0).

http://creativecommons.org/licenses/by/4.0/

(c) (i) Open Access

\begin{abstract}
A comprehensive in vitro study on single and sequential extraction methods for $\mathrm{Cu}$ exraction by different extractants of distinct chemical nature from some peat soils of Bangladesh was conducted to assess the pattern of metal-extractability in drying and wetting sequences. Samples were collected from peat basins of two different districts of Bangladesh (Gopalgonj and Bagerhat) and an incubation study was designed and conducted in which soils were incubated to three alternate drying and wetting cycles for 21 days. Single and sequentially extracted $\mathrm{Cu}$ ions in all three cycles and by all three selective extractants were compared. Maximum amount of $\mathrm{Cu}$ was extracted in drying days and $1 \mathrm{M} \mathrm{HCl}$ extracted the largest proportion of $\mathrm{Cu}$ from all the soils in each incubation time. Conversely, $1 \mathrm{M} \mathrm{NH}_{4} \mathrm{Cl}$ was the least effective extractant for extracting $\mathrm{Cu}$ by both single and sequential process in either day of incubation. Considerable amount of $\mathrm{Cu}$ was extracted by $0.005 \mathrm{M}$ DTPA in dry periods. In general, single extraction was found to be more effective in extracting $\mathrm{Cu}$ in the alternate drying and wetting cycles from the peat soil samples except for $1 \mathrm{M} \mathrm{HCl}$ in initial drying days.
\end{abstract}

\section{Keywords}

Copper, Single and Sequential Extraction, $\mathrm{NH}_{4} \mathrm{Cl}, \mathrm{DTPA}, \mathrm{HCl}$, Peat Soil

\section{Introduction}

Peat soils generally consist of partially decomposed organic matter, derived mostly from plant material, which has accumulated under conditions of water logging and oxygen deficiency. These are organic soils containing a minimum of $20 \%$ organic matter with as much as $60 \%$ of the mineral matter is clay. There are ar- 
guments about definitions of peat with organic matter content higher than $30 \%$ and thickness greater than $30 \mathrm{~cm}$. Organic material occupies more than half of the upper $80 \mathrm{~cm}$ of the peat occurring at the surface or be buried under up to 15 inches of mineral soils or occupy one or more layers separately in layers of mineral matter [1]. In some cases, peat and mineral layers may occur at the top of the profile. They usually possess highly acidic environment with lower available nutrients, although reserved organic matter acts as total nutrient pool.

In Bangladesh, peat soils are found in Gopalgonj, Bagerhat and adjoining parts of Khulna, Barishal and Jessore districts occupying an area of about 1,30,005 hectares which is about $1.06 \%$ of the total area of Bangladesh [2]. Peat soils are located mainly between the Ganges River Floodplain and the Ganges Tidal Floodplain regions of Bangladesh [2]. These soils are seasonally flooded, poorly to very poorly drained and have muck in an alternate emergence. Usually they contain a very high amount of organic matter which acts as reservoir of almost all the macro and micronutrients except Zn [3]. Such higher content of organic matter and heavy metal sometimes become major constraints for peat soils [2]. Most of the ions become available in oxidizing condition when water recedes from the soil and become unavailable again in reduced soil conditions.

To have a detail idea about the extractability of one of the native micronutrients, Copper $(\mathrm{Cu})$, three different extractants of distinct chemical character; unbuffered salt $\left(\mathrm{NH}_{4} \mathrm{Cl}\right)$, strong acid $(\mathrm{HCl})$ and chelating agent (DTPA), were used in this study. These extractants were used both for single and sequential extraction of $\mathrm{Cu}$ in dry and wet condition to have a clear concept about the origin, mode of occurrence, mobility, biological and physicochemical availability of the trace elements as well as to provide a convenient way to determine the trace elements associated with soils and sediments [4]. Thus, the extractants were used in this study to figure out the status of $\mathrm{Cu}$ content and it's extractability with these extractants during dry and wet cycles in some peat soils of Bangladesh.

\section{Materials and Methods}

\subsection{Sample Collection and Preparation}

Ten samples of peat soils were collected from Gopalganj and Bagerhat districts of Bangladesh to figure out $\mathrm{Cu}$ concentrations in those soils as well as to identify their extractability with different extractants. Following the recommendations of the Soil Survey Staff of the USDA [5] for composite sampling, soil samples were collected from $0-15 \mathrm{~cm}$ depth of the profiles. The geo-locations of the samples are shown in Table 1.

After collection, the peat samples were dried under the sunlight and noticeable non-soil materials including roots and debris were removed manually. The dried soils were then divided into two parts; one portion for incubation study and the other part for chemical analyses. For the incubation study, samples were ground with wooden hammer to crush the larger aggregates, screened through a $5 \mathrm{~mm}$ stainless steel sieve [6] and mixed thoroughly to make the composite sam- 
ples. On the other hand, for the chemical analyses, another portion of the samples was ground to pass through a $0.5 \mathrm{~mm}$ wire sieve [6] and stored in plastic pots.

\subsection{Chemical Analyses of Background Sample}

\subsubsection{Determination of Basic Chemical (Organic Matter and Organic} Carbon) and Physico-Chemical Properties (pH) of Soils

Some basic properties of the peat samples were determined before doing extractions of soils with selected extractants. To know the initial condition of the soils, $\mathrm{pH}$ of the samples were determined by $\mathrm{pH}$ meter from soil-water suspensions of 1:2.5 ratio [7]. Total content of organic carbon was also measured using the Walkley and Black wet oxidation process [8]. Based on the assumption of containing 58\% of organic carbon in organic matters of average soils [9], the calculated value of organic carbon was multiplied by the conventional Van Bemmelen's factor of 1.724 to get the total organic matter content of the samples [10].

\subsubsection{Determination of Extractable $\mathrm{Cu}$}

The samples were extracted with different extractants using single and sequential extraction procedures. Copper extractability of extractants by both the procedures was compared in the samples before and after incubation study. The list of extractants used for determining $\mathrm{Cu}$ availability is shown in Table 2.

Table 1. Location of the sampling sites.

(a) Gopalganj district

\begin{tabular}{ccccccc}
\hline \multirow{2}{*}{$\begin{array}{c}\text { Serial } \\
\text { No. Sample }\end{array}$} & Name & Latitude & Longitude & \multicolumn{3}{c}{ Area Details } \\
\cline { 5 - 7 } 1 & $\mathrm{~S}(\mathrm{G} 1)$ & $23^{\circ} 01.891^{\prime} \mathrm{N}$ & $89^{\circ} 55.891^{\prime} \mathrm{E}$ & Bajuni & Kajulia & $\begin{array}{c}\text { Gopalganj } \\
\text { Sador }\end{array}$ \\
2 & $\mathrm{~S}(\mathrm{G} 2)$ & $23^{\circ} 05.512^{\prime} \mathrm{N}$ & $89^{\circ} 59.261^{\prime} \mathrm{E}$ & Machh para & Kolabari & Kotalipara \\
3 & $\mathrm{~S}(\mathrm{G} 3)$ & $23^{\circ} 02.611^{\prime} \mathrm{N}$ & $90^{\circ} 01.050^{\prime} \mathrm{E}$ & $\begin{array}{c}\text { Chhoto } \\
\text { Digholia }\end{array}$ & Radhaganj & Gopalganj \\
4 & $\mathrm{~S}(\mathrm{G} 4)$ & $22^{\circ} 55.206^{\prime} \mathrm{N}$ & $89^{\circ} 54.460^{\prime} \mathrm{E}$ & $\begin{array}{c}\text { Baladanga } \\
\text { Bnion }\end{array}$ & Patgati & Tungipara \\
5 & $\mathrm{~S}(\mathrm{G} 5)$ & $22^{\circ} 51.630^{\prime} \mathrm{N}$ & $89^{\circ} 58.458^{\prime} \mathrm{E}$ & Karfa & Dumuria & Tungipara \\
\hline
\end{tabular}

(b) Bagerhat district

\begin{tabular}{ccccccc}
\hline \multirow{2}{*}{$\begin{array}{c}\text { Serial } \\
\text { No. }\end{array}$} & $\begin{array}{c}\text { Sample } \\
\text { Name }\end{array}$ & Latitude & Longitude & \multicolumn{3}{c}{ Area Details } \\
\cline { 5 - 7 } & & Village & Union & Upazila \\
\hline 6 & S (B6) & $22^{\circ} 49.566^{\prime} \mathrm{N}$ & $89^{\circ} 50.594^{\prime} \mathrm{E}$ & Kaligati & Shibpur & Chitalmari \\
7 & $\mathrm{~S}(\mathrm{~B} 7)$ & $22^{\circ} 49.632^{\prime} \mathrm{N}$ & $89^{\circ} 50.633^{\prime} \mathrm{E}$ & Kaligati & Shibpur & Chitalmari \\
8 & $\mathrm{~S}(\mathrm{~B} 8)$ & $22^{\circ} 50.605^{\prime} \mathrm{N}$ & $89^{\circ} 50.115^{\prime} \mathrm{E}$ & Kachuria & Kodalia & Mollahat \\
9 & $\mathrm{~S}(\mathrm{~B} 9)$ & $22^{\circ} 51.656^{\prime} \mathrm{N}$ & $89^{\circ} 49.334^{\prime} \mathrm{E}$ & Machuarkul & Barobaria & Chitalmari \\
10 & $\mathrm{~S} \mathrm{(B10)}$ & $22^{\circ} 49.133^{\prime} \mathrm{N}$ & $89^{\circ} 50.544^{\prime} \mathrm{E}$ & Kendua & Gaola & Mollahat \\
\hline
\end{tabular}


Table 2. List of extractants used for single and sequential extraction of $\mathrm{Cu}$.

\begin{tabular}{lll}
\hline Extractant type & Extractants used & Reason for using \\
\hline $\begin{array}{ll}\text { 1. Dilute Solutions of either weak acids (Acetic acid, } \\
0.1 \mathrm{M} \mathrm{HCl}) \text { or strong acids }\left(1 \mathrm{M} \mathrm{HCl}, 1 \mathrm{M} \mathrm{HNO}_{3}\right)\end{array}$ & $1 \mathrm{M} \mathrm{HCl}$ & $\begin{array}{l}\text { Releases elements from the non-residual metals and } \\
\text { silicate mineral matrix. }\end{array}$ \\
$\begin{array}{ll}\text { 2. Complexing extractants }(0.005 \mathrm{M} \mathrm{DTPA}, \mathrm{EDTA}) \\
\text { 3. Weak replacement of non-buffered salts }\left(\mathrm{MgCl}_{2},\right.\end{array}$ & $\begin{array}{l}1 \mathrm{M} \mathrm{NH}_{4} \mathrm{Cl} \\
\left.\mathrm{CaCl}_{2}, \mathrm{NH}_{4} \mathrm{Cl}, \mathrm{NH}_{4} \mathrm{NO}_{3}\right)\end{array}$ & $\begin{array}{l}\text { Releases ions or nutrients that are bound organically } \\
\text { Releases ions from exchange sites on the soil } \\
\text { solid-phase }\end{array}$ \\
\hline
\end{tabular}

\section{1) Single Extraction}

All the samples were extracted using each of the extractants (Table 2) in three replicates. Total amount of the extractants required for extracting the samples were calculated and prepared using standard procedure. The specific ratio of soil to extractant was followed for each extractant. For extractions, soil samples and extractants were shaken in $250 \mathrm{ml}$ conical flasks with a mechanical shaker for certain periods to make a suspension. Prepared suspensions were then filtered through Whatman 44 filter papers.

\section{2) Sequential Extraction}

Three different chemical phases, viz., $1 \mathrm{M} \mathrm{NH}_{4} \mathrm{Cl}$ extractable (exchangeable), $0.005 \mathrm{M}$ DTPA extractable (organically bound) and $1 \mathrm{M} \mathrm{HCl}$ extractable fractions were tried in the sequential extraction procedure.

Four grams of $0.5 \mathrm{~mm}$ sieved soil sample with $40 \mathrm{ml}$ of extractants (1:10) were placed in a $50 \mathrm{ml}$ polycarbonate centrifuge tube to perform extractions sequentially. A brief summary of the sequential extraction procedures are given below in Table 3.

All the samples were centrifuged at a rate of 2000 rpm for 5 minutes; after each extraction procedure samples were filtered.

The basic difference between single and sequential extraction is the single extraction procedure involves one simple extraction scheme to extract an element from solid surface; whereas the sequential extraction procedure involves a number of extraction schemes where the extractants are applied sequentially to extract an element from solid surface by increasing reactivity.

\subsubsection{Determination of Total $\mathrm{Cu}$}

The peat samples were digested with aqua-regia $\left(\mathrm{HNO}_{3}: \mathrm{HCl}=1: 3\right)$ to determine the total concentration of $\mathrm{Cu}$ in soils. One gram of sample was taken for digestion with $20 \mathrm{ml}$ aqua-regia and heated for approximately 3 hours on a sand bath at $150^{\circ} \mathrm{C}$ temperature. After digestion, samples were diluted to $100 \mathrm{ml}$ volume with distilled water, stored and filtered before further analysis [11]. The concentration of $\mathrm{Cu}$ was determined from the diluted samples by using atomic absorption spectrophotometer (AAS).

\subsection{Incubation Study}

An in vitro incubation study was conducted in a seven days cycle of alternate wetting and drying in the laboratory under ambient temperature. 
Table 3. Outline of the sequential extraction procedures.

\begin{tabular}{ll}
\hline Symbols & Particulars \\
\hline F1 & $\begin{array}{l}4 \text { gm of soil samples was extracted with } 40 \mathrm{ml} \text { of } 1 \mathrm{M} \mathrm{NH} 4 \mathrm{Cl} \text { after shaking for } \\
2 \text { hours (h) at room temperature on a mechanical shaker. }\end{array}$ \\
F2 & $\begin{array}{l}\text { The residue from F1 was extracted with } 40 \mathrm{ml} \text { of } 0.005 \mathrm{M} \mathrm{DTPA} \text { after shaking } \\
\text { for } 2 \text { hours (h) at room temperature on a mechanical shaker. }\end{array}$ \\
F3 & $\begin{array}{l}\text { The residue from F2 was extracted with } 40 \mathrm{ml} \text { of } 1 \mathrm{M} \mathrm{HCl} \text { after shaking for } 2 \\
\text { hours (h) at room temperature on a mechanical shaker. }\end{array}$ \\
\hline
\end{tabular}

For the incubation experiment, $300 \mathrm{~g}$ of air dried, $5 \mathrm{~mm}$-sieved soil sample was taken in plastic pots and incubated in alternate cycles of wetting and drying. In the first seven days of wetting cycle soils were saturated every alternate day to ensure field moisture condition. No water was added in the soils in the next seven days of drying cycle. Again, the wetting procedure was repeated for the next seven days of wetting cycle. Therefore, 1 - 7 days were wetting cycles, 8 - 14 days were the drying period and $15-21$ days were the wetting cycle again.

Soils in the pots were mixed thoroughly for ensuring uniform sampling for further analysis at the end of each incubation cycle. Thereafter, the samples were collected randomly for further single and sequential analyses. For each of the extraction period, available concentration of $\mathrm{Cu}$ was analyzed following the same procedure as stated above in section 2.2.4.1 and 2.2.4.2. A brief detail of the extractants and the mode of extraction are shown in Table 4.

\subsection{Statistical Analysis of Data}

A general-purpose statistical software, STATA, (version 14) was used to calculate correlations among various pairs. Microsoft Excel package was also used for the statistical and graphical evaluations.

\section{Results and Discussion}

\subsection{Initial Chemical and Physico-Chemical Conditions of the Soils before Incubation}

\subsection{1. pH, Organic Carbon and Organic Matter Content of the Collected Soil Samples}

Some general but important chemical and physico-chemical properties of the soils like $\mathrm{pH}$, organic carbon and organic matter percentage were analyzed from the collected peat samples in order to know the initial status of $\mathrm{Cu}$ content of the soils. Ten samples were collected from the peat soils of Gopalgonj and Bagerhat districts and designated as $\mathrm{S}(\mathrm{G})$ and $\mathrm{S}(\mathrm{B})$ respectively. The background information about the $\mathrm{pH}$, organic carbon and organic matter content of the selected soil samples are given below in Table 5 .

Table 5 explains that the average $\mathrm{pH}$ of the Bagerhat peat basins $\mathrm{S}(\mathrm{B})$ were recorded in the neutral soil $\mathrm{pH}$ range (6.6 - 7.3) whereas the samples from Gopalgonj peats $\mathrm{S}(\mathrm{G})$ were classified as "Slightly acidic $(6.1-6.5)$ " as per the Soil Survey Manual [15]. 
Table 4. Summary of the extraction methods used in the present study.

\begin{tabular}{cccc}
\hline Extractants & Ratio(w/v)/Time/Temperature & Pool & Reference \\
\hline $1 \mathrm{M} \mathrm{NH} 4 \mathrm{Cl}$ & $1: 6 / 16 \mathrm{~h} /$ room temperature & $\begin{array}{c}\text { Neutral salt } \\
\text { soluble/exchange }\end{array}$ & {$[12]$} \\
$0.005 \mathrm{M} \mathrm{DTPA}$ & $1: 2 / 2 \mathrm{~h} /$ room temperature & Chelating, extractable & {$[13]$} \\
$1 \mathrm{M} \mathrm{HCl}$ & $1: 33.3 / 2 \mathrm{~h} /$ room temperature & Weak acid extractable & {$[14]$} \\
\hline
\end{tabular}

Table 5. Initial $\mathrm{pH}$, organic carbon and organic matter content of the soil samples.

\begin{tabular}{cccc}
\hline Sample & $\mathrm{pH}$ & Organic carbon (\%) & Organic matter (\%) \\
\hline $\mathrm{S}(\mathrm{G} 1)$ & 6.36 & 13.21 & 22.77 \\
$\mathrm{~S}(\mathrm{G} 2)$ & 6.22 & 11.9 & 20.52 \\
$\mathrm{~S}(\mathrm{G} 3)$ & 6.29 & 13.18 & 22.72 \\
$\mathrm{~S}(\mathrm{G} 4)$ & 6.41 & 9.93 & 17.12 \\
$\mathrm{~S}(\mathrm{G} 5)$ & 6.35 & 9.77 & 16.84 \\
Average & 6.33 & 11.60 & 19.99 \\
$\mathrm{~S}(\mathrm{~B} 6)$ & 6.71 & 8.57 & 14.8 \\
$\mathrm{~S}(\mathrm{~B} 7)$ & 6.79 & 7.94 & 13.7 \\
$\mathrm{~S}(\mathrm{~B} 8)$ & 7.13 & 6.38 & 11.0 \\
$\mathrm{~S}(\mathrm{~B} 9)$ & 6.85 & 6.99 & 12.1 \\
$\mathrm{~S}(\mathrm{~B} 10)$ & 6.92 & 7.24 & 12.5 \\
Average & 6.88 & 7.42 & 12.80 \\
\hline
\end{tabular}

On the other hand, the mean organic carbon content of $S(B)$ samples $(7.42 \%)$ was relatively lower than the $S(G)$ samples $(11.60 \%)$. These values support the hypothesis that the content of higher organic carbons usually lowers the $\mathrm{pH}$ of the soil. Correspondingly, the organic matter content was assessed by multiplying the organic carbon value with the Van Bemmelen's factor (1.724) [10]. As a result, more organic matter contents were recorded in $S(G)$ sites (average 19.99\%) than $\mathrm{S}(\mathrm{B})$ sites (average $12.80 \%$ ).

\subsubsection{Total and Extractable Cu Content in Background Soil Samples}

A portion of the peat samples were analyzed for determining initial total and extractable content of $\mathrm{Cu}$ in soils. It can be declared from Table 6 that the peat basins of Bagerhat district, $\mathrm{S}(\mathrm{B})$ samples, contain more total $\mathrm{Cu}$ on an average $(72.04 \mathrm{mg} / \mathrm{kg})$ than the Gopalgonj peats, $\mathrm{S}(\mathrm{G})(55.04 \mathrm{mg} / \mathrm{kg})$. The two major factors that affect soil $\mathrm{Cu}$ content are $\mathrm{pH}$ and organic matter level of the soil. Copper level drops with the increase of organic matter in soils. As the $S(G)$ samples contain more organic matter, their $\mathrm{Cu}$ level was lower than the $\mathrm{S}(\mathrm{B})$ samples. Moreover, comparatively lower $\mathrm{pH}$ of $\mathrm{S}(\mathrm{G})$ also lead to lower the total $\mathrm{Cu}$ content as acidic soils are most likely to be lower in $\mathrm{Cu}$ content [16]. However, the total concentration of metals usually has poor correlations with bio-availability of that metal to plants or organisms [17]. 
Table 6. Cu content in peat soil samples before incubation.

\begin{tabular}{|c|c|c|c|c|c|c|c|}
\hline \multirow[t]{2}{*}{ Sample } & \multirow[t]{2}{*}{$\begin{array}{l}\text { Total Cu } \\
(\mathrm{mg} / \mathrm{kg})\end{array}$} & \multicolumn{2}{|c|}{$\begin{array}{c}\text { Extraction of } \\
\text { Cu by } 1 \mathrm{M} \mathrm{NH} \mathrm{NH}_{4} \mathrm{Cl} \\
(\mathrm{mg} / \mathrm{kg})\end{array}$} & \multicolumn{2}{|c|}{$\begin{array}{c}\text { Extraction of Cu by } \\
0.005 \mathrm{M} \mathrm{DTPA} \\
(\mathrm{mg} / \mathrm{kg})\end{array}$} & \multicolumn{2}{|c|}{$\begin{array}{l}\text { Extraction of } \\
\mathrm{Cu} \text { by } 1 \mathrm{M} \mathrm{HCl} \\
(\mathrm{mg} / \mathrm{kg})\end{array}$} \\
\hline & & Single & Sequential & Single & Sequential & Single & Sequential \\
\hline $\mathrm{S}(\mathrm{G} 1)$ & 50.1 & 0.391 & 2.879 & 2.852 & 0.001 & 17.931 & 21.3 \\
\hline $\mathrm{S}(\mathrm{G} 2)$ & 54.3 & 0.712 & 0.09 & 4.404 & 0.003 & 20.564 & 36.06 \\
\hline $\mathrm{S}(\mathrm{G} 3)$ & 47 & 1.435 & 0.061 & 4.782 & 0.002 & 18.431 & 49.46 \\
\hline $\mathrm{S}(\mathrm{G} 4)$ & 64.6 & 4.039 & 0.634 & 4.926 & 0.004 & 29.93 & 50.56 \\
\hline$S(G 5)$ & 59.2 & 1.069 & 0.325 & 4.136 & 0.001 & 20.231 & 32.73 \\
\hline Average & 55.04 & 1.529 & 0.798 & 4.220 & 0.002 & 21.417 & 38.022 \\
\hline$S(B 6)$ & 67.4 & 1.081 & 0.518 & 4.644 & 0.009 & 24.397 & 61.43 \\
\hline$S(B 7)$ & 64.7 & 0.577 & 0.22 & 4.368 & 0.004 & 22.764 & 65.36 \\
\hline S(B8) & 56.4 & 0.265 & 0.69 & 2.498 & 0.002 & 23.93 & 67.69 \\
\hline S(B9) & 89.9 & 0.709 & 0.167 & 3.018 & 0.008 & 27.863 & 32.2 \\
\hline$S(B 10)$ & 81.8 & 0.865 & 0.445 & 4.476 & 0.009 & 19.264 & 49.13 \\
\hline Average & 72.04 & 0.699 & 0.408 & 3.801 & 0.006 & 23.644 & 55.162 \\
\hline
\end{tabular}

In the case of determining extractable $\mathrm{Cu}$ concentration in both $\mathrm{S}(\mathrm{G})$ and $\mathrm{S}(\mathrm{B})$ samples, $1 \mathrm{M} \mathrm{HCl}$ was found to be the most efficient extractants for both single and sequential extractions of the samples. On the other hand, $1 \mathrm{M} \mathrm{NH} \mathrm{NH}_{4} \mathrm{Cl}$ was found to be least efficient for extracting $\mathrm{Cu}$ from both $\mathrm{S}(\mathrm{G})$ and $\mathrm{S}(\mathrm{B})$ samples in single extraction procedure; whereas 0.005M DTPA extracted minimum $\mathrm{Cu}$ from both the soil samples in sequential extraction process.

As DTPA extractant usually represents the plant-available fractions [13] [18] [19] it can be said that a little portion is available to plants. DTPA is evidenced to form soluble metal complexes thus reduces metal activity in the solutions. However, there was a wide difference in extracting $\mathrm{Cu}$ by the extractants for the samples of both the sites.

\subsection{Copper Content of Soils by Different Extractants after Incubation}

Single and sequential extraction of incubated soils in each of the drying and wet-

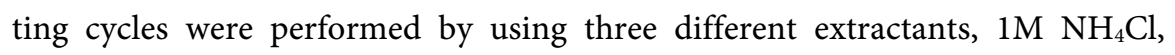
$0.005 \mathrm{M}$ DTPA and $1 \mathrm{M} \mathrm{HCl}$. Incubation was carried out for $1-7$ days (dry cycle), 8 - 14 days (wet cycle) and 15 - 21 days (dry cycle).

\subsubsection{Single and Sequential Extraction of $\mathrm{Cu}$ by $1 \mathrm{M} \mathrm{NH}_{4} \mathrm{Cl}$ after Incubation}

The concentrations of $1 \mathrm{M} \mathrm{NH}_{4} \mathrm{Cl}$ extractable $\mathrm{Cu}(\mathrm{mg} / \mathrm{kg})$ in the samples at different incubation days are presented in Table 7. 
Table 7. $1 \mathrm{M} \mathrm{NH}_{4} \mathrm{Cl}$ extractable $\mathrm{Cu}$ contents $(\mathrm{mg} / \mathrm{kg})$ in peat soil samples at different Incubation days by single and sequential extraction.

\begin{tabular}{ccccccc}
\hline Incubation days $\rightarrow$ & \multicolumn{2}{c}{$0-7$ days (dry) } & \multicolumn{2}{c}{$8-14$ days (wet) } & \multicolumn{2}{c}{$15-21$ days (dry) } \\
\hline Sample $\downarrow$ & Single & Sequential & Single & Sequential & Single & Sequential \\
\hline S(G1) & 0.391 & 0.879 & 0.061 & 0.488 & 0.793 & 0.099 \\
S(G2) & 0.712 & 0.09 & 0.103 & 0.468 & 1.027 & 0.089 \\
S(G3) & 1.435 & 0.061 & 0.331 & 0.996 & 0.991 & 0.093 \\
S(G4) & 1.039 & 0.634 & 0.115 & 0.246 & 1.069 & 0.088 \\
S(G5) & 1.069 & 0.325 & 0.097 & 0.816 & 1.038 & 0.079 \\
Average & 0.929 & 0.398 & 0.141 & 0.603 & 0.984 & 0.090 \\
\hline S(B6) & 1.081 & 0.518 & 0.229 & 0.624 & 0.577 & 0.099 \\
S(B7) & 0.577 & 0.22 & 0.055 & 0.666 & 1.837 & 0.067 \\
S(B8) & 0.265 & 0.69 & 0.445 & 0.594 & 1.519 & 1.199 \\
S(B9) & 0.709 & 0.167 & 0.463 & 0.468 & 1.597 & 1.629 \\
S(B10) & 0.865 & 0.445 & 0.523 & 1.074 & 2.257 & 2.709 \\
Average & $\mathbf{0 . 6 9 9}$ & $\mathbf{0 . 4 0 8}$ & $\mathbf{0 . 3 4 3}$ & $\mathbf{0 . 6 8 5}$ & $\mathbf{1 . 5 5 7}$ & $\mathbf{1 . 1 4 1}$ \\
\hline
\end{tabular}

It is apparent from Table 7 that the concentration of available $\mathrm{Cu}$ increases in drying days and decreases with wetting of the soil. The concentration increases further while drying the soils. For samples from both the sites, $S(G)$ and $S(B)$, extractable $\mathrm{Cu}$ content increase even more in the second drying cycle (0.984 and $0.090 \mathrm{mg} / \mathrm{kg} \mathrm{Cu}$ for single and sequential extactions of $\mathrm{S}(\mathrm{G})$ samples; and 1.557 and $1.141 \mathrm{mg} / \mathrm{kg} \mathrm{Cu}$ for single and sequential extactions of $\mathrm{S}(\mathrm{B})$ samples) than the first one $(0.929$ and $0.398 \mathrm{mg} / \mathrm{kg} \mathrm{Cu}$ for single and sequential extactions of $\mathrm{S}(\mathrm{G})$ samples; and 0.699 and $0.408 \mathrm{mg} / \mathrm{kg} \mathrm{Cu}$ for single and sequential extactions of $\mathrm{S}$ (B) samples). The organic carbons present in the soils become oxidized with the release of water from the soils. As a result, in the drying periods, the organo-mineral complexes are broken and $\mathrm{Cu}$ ions get released to the soil solution to become available for plants.

In the subsequent wet cycle, the extractable $\mathrm{Cu}$ concentration was found to be decreased. The accumulation and immobilization of remaining organic matters in the reduced soil condition might help $\mathrm{Cu}$ ions to form complex or to get fixed in colloid surfaces leading to lower extractability by single $(0.141 \mathrm{mg} / \mathrm{kg} \mathrm{Cu}$ for $\mathrm{S}(\mathrm{G})$ and $0.343 \mathrm{mg} / \mathrm{kg} \mathrm{Cu}$ for $\mathrm{S}(\mathrm{B})$ samples) and sequential $(0.603 \mathrm{mg} / \mathrm{kg} \mathrm{Cu}$ for $\mathrm{S}(\mathrm{G})$ and $0.685 \mathrm{mg} / \mathrm{kg} \mathrm{Cu}$ for $\mathrm{S}(\mathrm{B})$ samples) extraction processes.

The reason for the decrease of $\mathrm{Cu}$ content in waterlogged soils could be the increased concentrations of $\mathrm{OM}$-bound $\mathrm{Cu}$ fraction as the lower values of Eh and higher values of $\mathrm{pH}$ in this system were propitious to the formation of metal-organic complexes [20] and microbial immobilization [21].

The graphical representation of $\mathrm{Cu}$ extractability trend by $1 \mathrm{M} \mathrm{NH}_{4} \mathrm{Cl}$ in single and sequential extraction process for Gopalgonj and Bagerhat soil samples are given below in Figure 1(a), Figure 1(b) and Figure 2(a), Figure 2(b): 


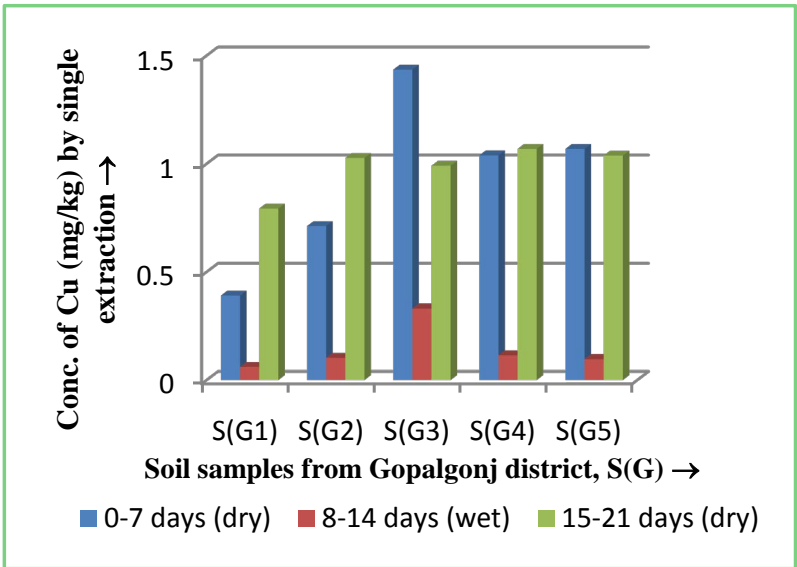

(a)

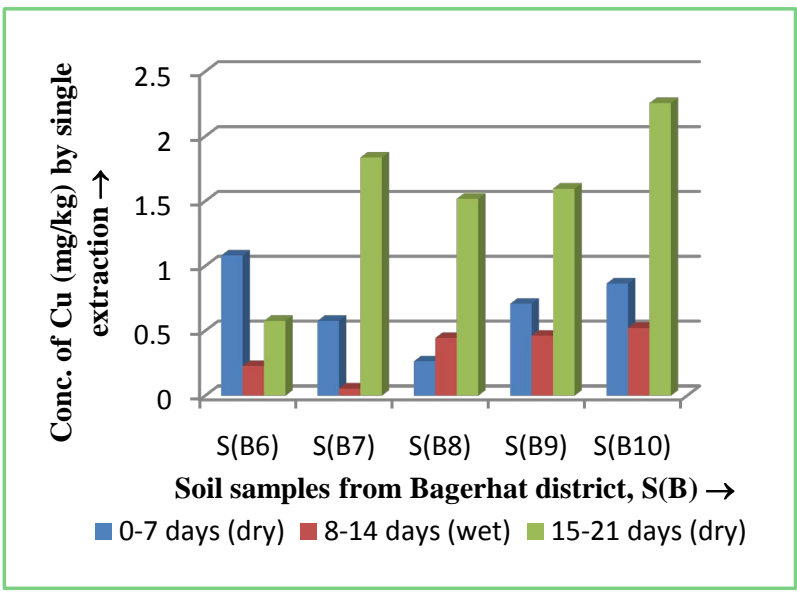

(b)

Figure 1. Single extraction of $\mathrm{Cu}$ by $1 \mathrm{M} \mathrm{NH}_{4} \mathrm{Cl}$ from samples of (a) Gopalganj's district, $S(G)$ and (b) Bagerhat district, $S(B)$ in 0 - 7 days (dry cycle), 8 - 14 days (wet cycle) and $15-21$ days (dry cycle) of incubation.

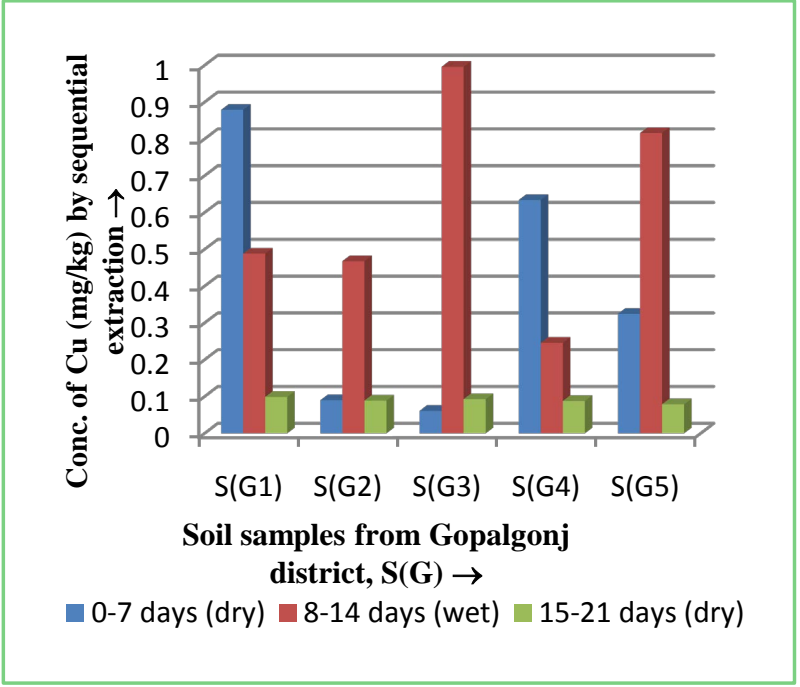

(a) 


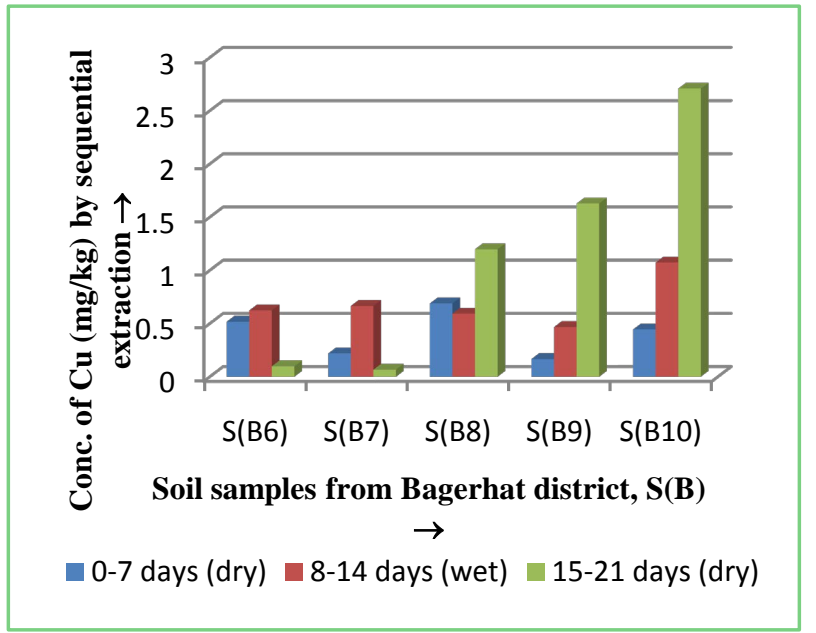

(b)

Figure 2. Sequential extraction of $\mathrm{Cu}$ by $1 \mathrm{M} \mathrm{NH}_{4} \mathrm{Cl}$ from samples of (a) Gopalganj's district, $\mathrm{S}(\mathrm{G})$ and (b) Bagerhat district, $\mathrm{S}(\mathrm{B})$ in 0 - 7 days (dry cycle), 8 - 14 days (wet cycle) and 15 21 days (dry cycle) of incubation.

The extractions in the mentioned three cycles carried no significant correlations except for the last drying cycle of $\mathrm{S}(\mathrm{B})$ samples ( $\mathrm{r}$ values 0.046 and 0.009 for single and sequential extractions).

\subsubsection{Single and Sequential Extraction of Cu by 0.005M DTPA after Incubation}

The concentrations of $0.005 \mathrm{M}$ DTPA extractable $\mathrm{Cu}(\mathrm{mg} / \mathrm{kg})$ in the soil samples at different incubation days are presented in Table 8 where it is noticeable that, for the $S(G)$ samples, the concentration of $\mathrm{Cu}$ was decreased from dry to wet conditions and increased again in the drying period in both the cases of single and sequential extractions. However, the $S(B)$ samples showed quite a different pattern indicating the decrease of DTPA extractable $\mathrm{Cu}$ from drying to wetting period and further decrease in subsequent drying cycle.

According to Table 8, 0.005M DTPA extracted maximum amount of $\mathrm{Cu}$ in drying period than the midst wetting days for $\mathrm{S}(\mathrm{G})$ samples. The result supports the finding that the extractability of $\mathrm{Cu}$ in soils increases by a factor of 1.3 to 1.5 from moist to dry condition [22]. Differing to the trend, DTPA extracted more $\mathrm{Cu}$ by both by single and sequential extraction $(3.067 \mathrm{mg} / \mathrm{kg}$ and $2.572 \mathrm{mg} / \mathrm{kg} \mathrm{Cu}$ respectively) in the wetting cycle than the last seven days of drying in $S(B)$ samples. A dissimilar finding was reported expressing that increased solubility and extractability of $\mathrm{Cu}$ in the drying periods of soils is a common phenomenon [23].

The trend of $\mathrm{Cu}$ extractability by $0.005 \mathrm{M}$ DTPA in single and sequential process for both the peat soil samples are given below in Figure 3(a), Figure 3(b) and Figure 4(a), Figure 4(b).

Statistically, the $S(B)$ samples from Bagerhat district showed a significant value for 0 - 7 days of drying cycle only (0.8003, significant at 10\%) among all the samples and in all three periods of alternate drying and wetting. 
Table 8. 0.005M DTPA extractable Cu contents $(\mathrm{mg} / \mathrm{kg})$ in peat soil samples at different incubation days by single and sequential extraction.

\begin{tabular}{ccccccc}
\hline Incubation days $\rightarrow$ & \multicolumn{2}{c}{$0-7$ days (dry) } & \multicolumn{2}{c}{8 - 14 days (wet) } & \multicolumn{2}{c}{15 - 21 days (dry) } \\
\hline Sample $\downarrow$ & Single & Sequential & Single & Sequential & Single & Sequential \\
\hline S(G1) & 2.852 & 0.914 & 2.146 & 4.04 & 3.26 & 0.498 \\
S(G2) & 4.404 & 1.083 & 2.763 & 1.19 & 2.96 & 0.987 \\
S(G3) & 4.782 & 1.046 & 3.38 & 3.78 & 6.79 & 1.456 \\
S(G4) & 2.368 & 0.778 & 1.751 & 0.67 & 3.57 & 0.578 \\
S(G5) & 4.136 & 1.002 & 2.174 & 0.63 & 2.17 & 0.578 \\
Average & 3.708 & 0.965 & 2.443 & 2.062 & 3.750 & 0.819 \\
\hline S(B6) & 9.446 & 2.095 & 5.088 & 2.85 & 1.8 & 0.089 \\
S(B7) & 9.398 & 1.801 & 1.989 & 2.8 & 1.91 & 0.99 \\
S(B8) & 6.498 & 1.998 & 3.333 & 2.16 & 0.97 & 0.879 \\
S(B9) & 10.006 & 2.645 & 1.579 & 0.84 & 2.33 & 0.59 \\
S(B10) & 4.476 & 0.986 & 3.347 & 4.21 & 0.82 & 1.627 \\
Average & 7.965 & $\mathbf{1 . 9 0 5}$ & 3.067 & 2.572 & 1.566 & 0.835 \\
\hline
\end{tabular}

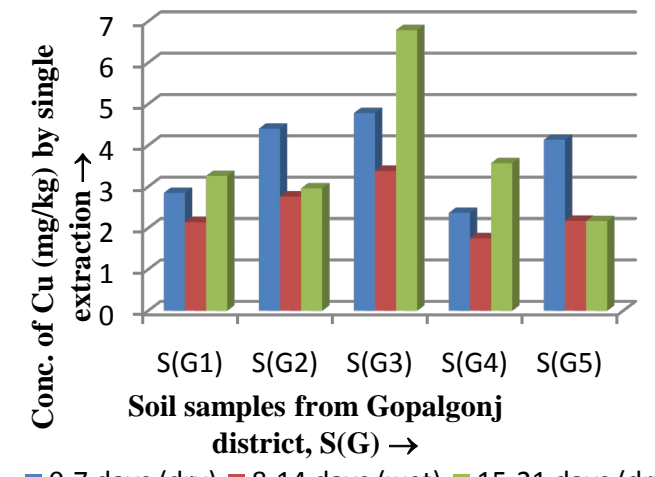

$\square$ 0-7 days (dry) $\square$ 8-14 days (wet) $\square$ 15-21 days (dry)

(a)

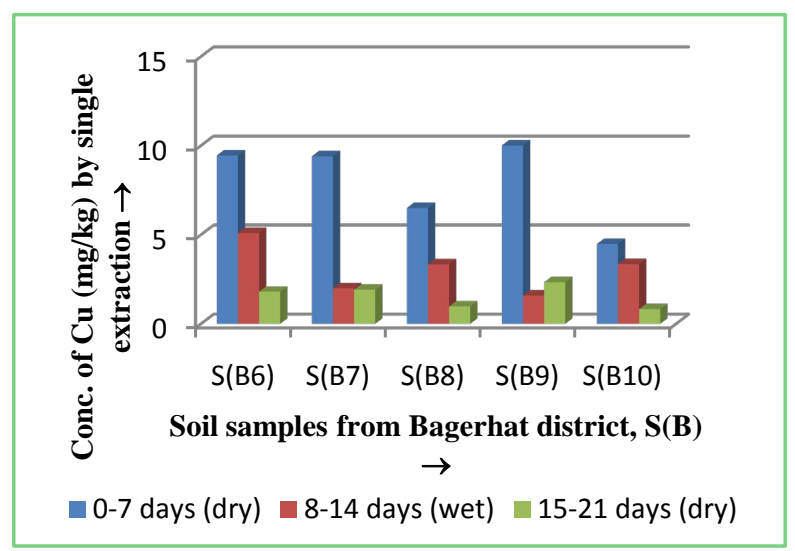

(b)

Figure 3. Single extraction of $\mathrm{Cu}$ by $0.005 \mathrm{M}$ DTPA from samples of (a) Gopalganj's district, $S(G)$ and (b) Bagerhat district, $S(B)$ in 0 - 7 days (dry cycle), 8 - 14 days (wet cycle) and 15 - 21 days (dry cycle) of incubation. 


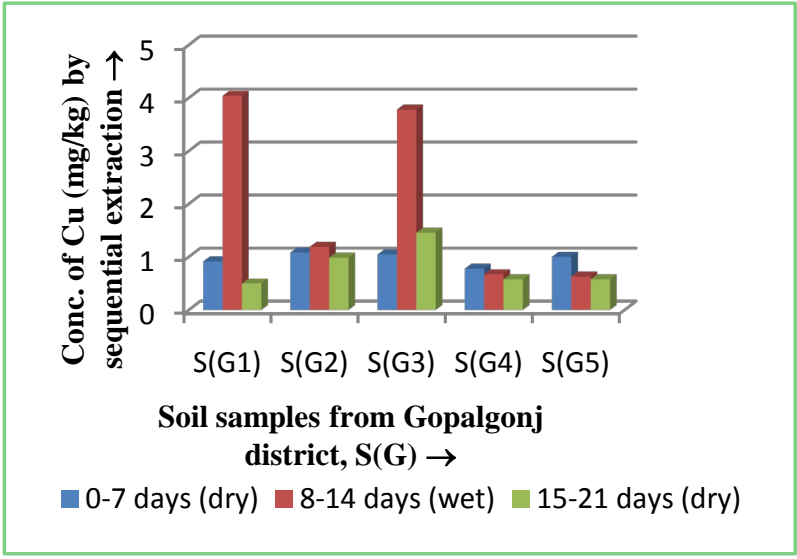

(a)

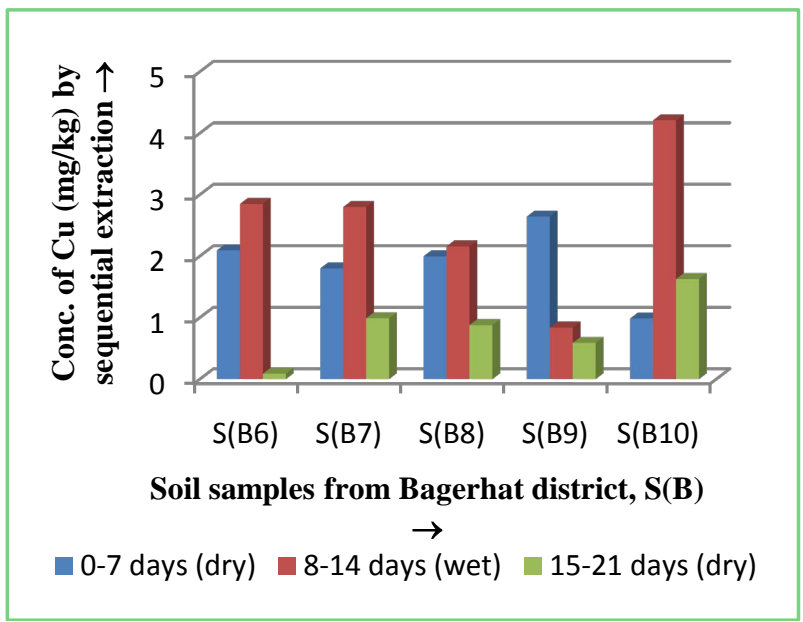

(b)

Figure 4. Sequential extraction of $\mathrm{Cu}$ by $0.005 \mathrm{M}$ DTPA from samples of (a) Gopalganj's district, $S(G)$ and (b) Bagerhat district, $\mathrm{S}(\mathrm{B})$ in 0 - 7 days (dry cycle), 8 - 14 days (wet cycle) and 15 - 21 days (dry cycle) of incubation.

In this experiment, the $0.005 \mathrm{M}$ DTPA extractable $\mathrm{Cu}$ was found to increase upon drying for $S(G)$ samples supporting the proposal of [22] explaining that increase in temperature during drying period can increase the extractability of $\mathrm{Cu}$, but contradictory to the results found for $\mathrm{S}(\mathrm{B})$ samples. DTPA helps to release ions from insoluble organo-mineral complexes [17] and clays [24]. The existing microorganisms of that environment may influence $\mathrm{Cu}$ extractability of DTPA upon rewetting [25].

\subsubsection{Single and Sequential Extraction of $\mathrm{Cu}$ by $1 \mathrm{M} \mathrm{HCl}$ after Incubation}

Single and sequentially extracted $\mathrm{Cu}(\mathrm{mg} / \mathrm{kg})$ concentrations by $1 \mathrm{M} \mathrm{HCl}$ in the peat soils from two different sites at different incubation days are presented in Table 9.

Samples showed an overall decrease of $\mathrm{Cu}$ concentration from drying to wetting sequence, although the amount of $\mathrm{Cu}$ extracted through sequential process 
Table 9. $1 \mathrm{M} \mathrm{HCl}$ extractable $\mathrm{Cu}$ contents $(\mathrm{mg} / \mathrm{kg})$ in peat soil samples at different incubation days by single and sequential extraction.

\begin{tabular}{ccccccc}
\hline Incubation days $\rightarrow$ & \multicolumn{2}{c}{$0-7$ days (dry) } & \multicolumn{2}{c}{$8-14$ days (wet) } & \multicolumn{2}{c}{$15-21$ days (dry) } \\
\hline Sample $\downarrow$ & Single & Sequential & Single & Sequential & Single & Sequential \\
\hline S(G1) & 17.931 & 21.308 & 9.734 & 5.509 & 7.302 & 3.842 \\
S(G2) & 20.564 & 36.062 & 6.966 & 4.971 & 6.647 & 1.04 \\
S(G3) & 18.431 & 49.465 & 6.941 & 4.178 & 13.835 & 2.136 \\
S(G4) & 29.93 & 50.964 & 6.806 & 5.139 & 9.001 & 0.992 \\
S(G5) & 20.231 & 32.737 & 7.168 & 3.313 & 13.401 & 1.049 \\
Average & 21.417 & 38.107 & 7.523 & 4.622 & 10.037 & 1.812 \\
\hline S(B6) & 24.397 & 61.73 & 11.203 & 13.688 & 24.733 & 3.45 \\
S(B7) & 22.764 & 65.366 & 15.787 & 9.512 & 18.44 & 1.89 \\
S(B8) & 23.93 & 67.691 & 10.967 & 7.106 & 8.773 & 6.33 \\
S(B9) & 27.863 & 32.222 & 21.649 & 10.55 & 10.897 & 6.933 \\
S(B10) & 19.264 & 49.134 & 10.925 & 8.099 & 8.909 & 1.908 \\
Average & 23.644 & 55.229 & 14.106 & 9.791 & 14.350 & 4.102 \\
\hline
\end{tabular}

was somewhat higher than the single one in case of the first seven days of drying. Although the value was reduced a little in the next wetting cycle, yet was higher than the previous cycle of wetting.

The extractant extracted more $\mathrm{Cu}$ from both the peat samples sequentially (38.107 mg/kg Cu for S(G) samples and $55.229 \mathrm{mg} / \mathrm{kg} \mathrm{Cu}$ for S(B) samples) than the single extraction process $(21.417 \mathrm{mg} / \mathrm{kg} \mathrm{Cu}$ for $\mathrm{S}(\mathrm{G})$ samples and 23.664 $\mathrm{mg} / \mathrm{kg} \mathrm{Cu}$ for $\mathrm{S}(\mathrm{B})$ samples in first seven days of drying. However, in other cases of wetting and drying periods, single extraction process was evidenced to bring more $\mathrm{Cu}$ ions in solution than the sequential process in both the peat samples.

A strong acid like $\mathrm{HCl}$ usually enhances oxidation and subsequent mineralization of the organic matters leading to release of locked or trapped $\mathrm{Cu}$ ions from the complexes. Additionally, the release of organic acids can also increase $\mathrm{Cu}$ availability in solutions in dry days. However, the reserve of $\mathrm{Cu}$ content as organo-mineral complexes can be increased in the subsequent wetting period because of lower to zero rate of oxidation.

Likewise, the findings of lower extractability in wetting cycle, [14] mentioned the formation of metal-organic complex from the organic matter and the binding material of heavy metals as the reasons for such changes in $\mathrm{Cu}$ extractability due to wetting and drying.

Graphically the trend of $\mathrm{Cu}$ extractability by $1 \mathrm{M} \mathrm{HCl}$ in single and sequential extraction process for the peat soil samples can be shown as follows (Figure 5(a), Figure 5(b) and Figure 6(a), Figure 6(b)):

Statistically, the dry period $\mathrm{Cu}$ contents were statistically significant for both the $S(G)$ and $S(B)$ samples ( $r$ value 0.0031 and 0.0049 respectively). However, the 
rest of the samples did not show any significant content of $\mathrm{Cu}$ concentration by extracting with $1 \mathrm{M} \mathrm{HCl}$ in either day of incubations.

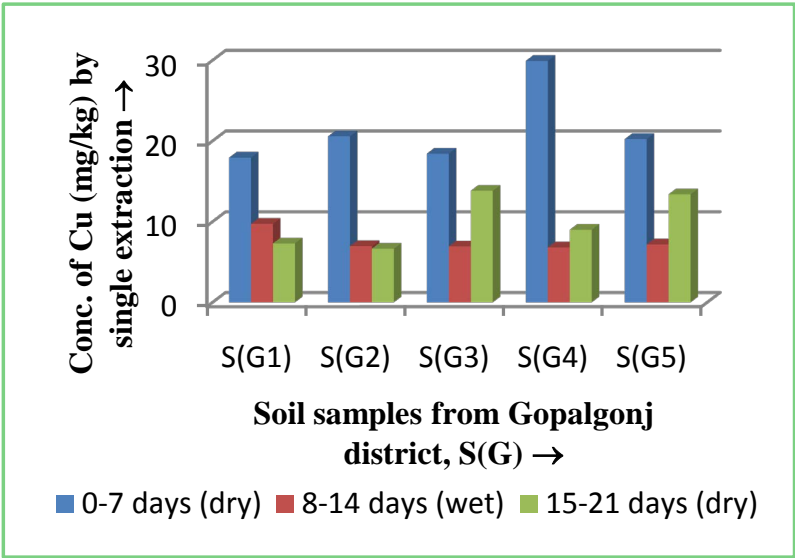

(a)

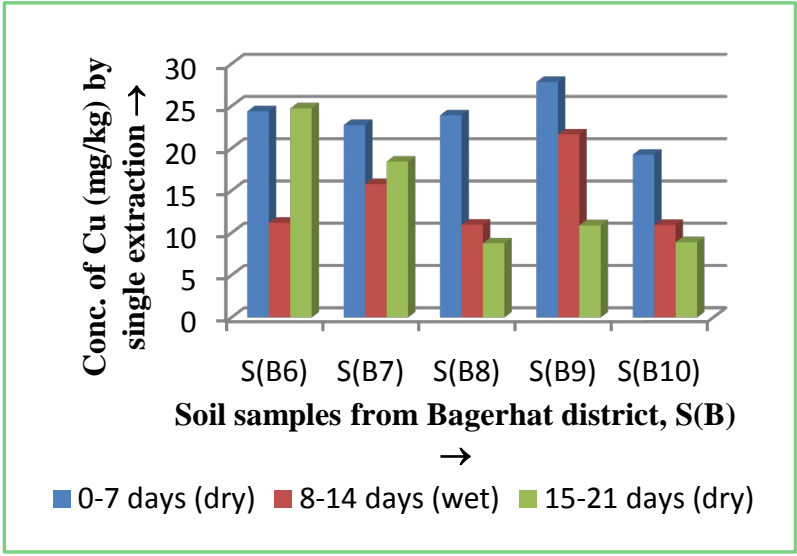

(b)

Figure 5. Single extraction of $\mathrm{Cu}$ by $1 \mathrm{M} \mathrm{HCl}$ from samples (a) Gopalganj's district, $\mathrm{S}(\mathrm{G})$ and (b) Bagerhat district, $\mathrm{S}(\mathrm{B})$ in 0 - 7 days (dry cycle), 8 - 14 days (wet cycle) and 15 - 21 days (dry cycle) of incubation.

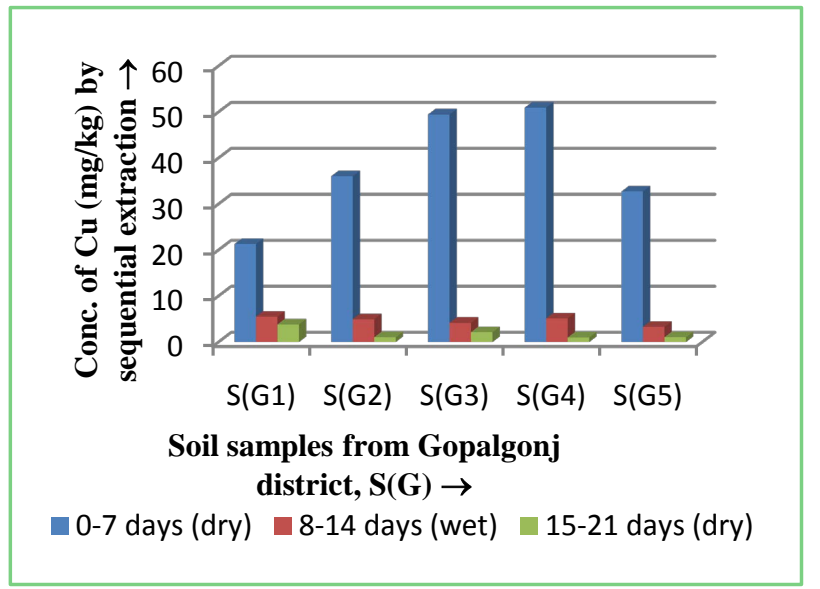

(a) 


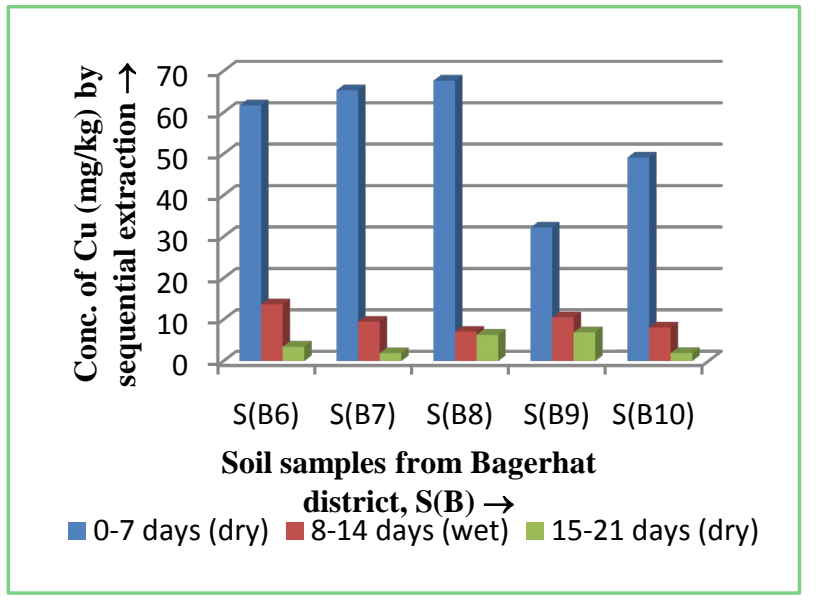

(b)

Figure 6. Sequential extraction of $\mathrm{Cu}$ by $1 \mathrm{M} \mathrm{HCl}$ from samples (a) Gopalganj's district, $\mathrm{S}(\mathrm{G})$ and (b) Bagerhat district, $\mathrm{S}(\mathrm{B})$ in 0 - 7 days (dry cycle), 8 - 14 days (wet cycle) and 15 21 days (dry cycle) of incubation.

Considering Tables 7-9 it can be postulated that single extraction process was found to be more efficient in extracting higher concentrations of $\mathrm{Cu}$ from the soil solutions than the sequential extraction procedure, which coincides with the findings of [26]. Although a disparate trend was figured out for $\mathrm{HCl}$ extractant in the first drying cycle of both the samples, however, it should be taken into consideration that single extraction signifies metal extractability than the phytoavailability of ions. Plant physiology and rhizosphere chemistry are two major factors that can alter the relation between extractants and available metal concentrations in tissues [27].

\section{Conclusions}

Among the three different extractants of three different chemical natures, acid extractants were found to extract available $\mathrm{Cu}$ ions more efficiently than others. $\mathrm{HCl}$ extracted maximum amount of $\mathrm{Cu}$ ions for both the samples from Gopalgonj and Bagerhat peats. Conversely, extractant from neutral salt, $\mathrm{NH}_{4} \mathrm{Cl}$, extracted ions from the soils with least efficacy both by single and sequential processes. However, extraction of $\mathrm{Cu}$ ions by chelating agents like 0.005M DTPA was also mentionable.

The concentration of extractable $\mathrm{Cu}$ increases with drying of the soils and decreases gradually with subsequent wetting of the samples. Overall, single extraction was found to be more efficient in extracting $\mathrm{Cu}$ from the soil solutions than the sequential extractions for the extractants except for $\mathrm{HCl}$ in first drying cycle.

\section{Acknowledgements}

The authors gratefully acknowledge the Bangladesh-Australia Centre for Environmental Research (BACER), University of Dhaka, Bangladesh and the Depart- 
ment of Soil and Environmental Sciences, University of Barishal, Bangladesh for providing all the necessary research facilities towards completion of this study.

\section{Conflicts of Interest}

The authors declare no conflicts of interest regarding the publication of this paper.

\section{References}

[1] Rahman, M.R. (2005) Peat-Basin Soils. In: Rahman, M.R., Ed., Soils of Bangladesh, Darpon Publication, Dhaka, 96-114.

[2] Imamul Huq, S.M. and Shoaib, J.U. (2013) Problem Soils. In: Hartemink, A. E., Ed., The Soils of Bangladesh, Springer, Dordrecht, Heidelburg, New York, 57-70. https://doi.org/10.1007/978-94-007-1128-0 7

[3] Masud, M.M., Moniruzzaman, M. and Rashid, M.M. (2011) Management and Conservation of Organic Peat Soils for Sustainable Crop Production in Bangladesh. Bulletin of the Institute of Tropical Agriculture, Kyushu University, 34, 93-101.

[4] Du Liang, G. (2011) Redox Metal Processes and Controls in Estuaries. In: Wolanski, E. and McLusky, D., Eds., Treaties on Estuarine and Coastal Science, Vol. 4, Academic Press, Cambridge, 115-141. https://doi.org/10.1016/B978-0-12-374711-2.00406-X

[5] United States Department of Agriculture (USDA) (1951) Soil Survey Manual. Handbook No. 18, Soil Survey Staff, Bureau of Plant Industry, Soils and Agricultural Engineering, United States Department of Agriculture, Washington DC, 205.

[6] Sanchary, I.J., Kabir, K. and Huq, S.M.I. (2019) Macro and Micro Nutrient Supply to Soil and Plants from Sugar Mill Mud. Agricultural Sciences, 10, 164-172. https://doi.org/10.4236/as.2019.102014

[7] Jackson, M.L. (1965) Soil Chemistry Analysis. Prentice-Hall, Madison, 183-192.

[8] Walkley, A. and Black, I.A. (1934) An Examination of Degtjareff Method for Determining Soil Organic Matter and a Proposed Modification of the Chromic Acid Titration Method. Soil Science, 37, 29-38. https://doi.org/10.1097/00010694-193401000-00003

[9] Piper, C.G. (1950) Soil and Plant Analysis. Hans Publishers, Bombay, 1-35.

[10] Imamul Huq, S.M. and Alam, M.D. (2005) A Handbook on Analyses of Soil, Plant and Water. Bangladesh Australia Centre for Environmental Research (BACER). University of Dhaka, Bangladesh, 1-246.

[11] Portman, J.E. and Riley, J.P. (1964) Determination of Arsenic in Seawater, Marine Plants and Silicate and Carbonate Sediments. Analytica Chimica Acta, 31, 509-519. https://doi.org/10.1016/S0003-2670(00)88870-4

[12] Krishnamurti, G.S.R., Huang, P.M., Van Rees, K.C.J., Kozak, L.M. and Rostead, H.P.W. (1995) A New Soil Test Method for Determination of Plant Available Cadmium in Soils. Commun. Communications in Soil Science and Plant Analysis, 26, 2857-2867. https://doi.org/10.1080/00103629509369493

[13] Lindsay, W.L. and Norvell, W.A. (1978) Development of DTPA Soil Test for Zinc, Iron, Manganese and Copper. Soil Science Society of America Journal, 42, 421-428. https://doi.org/10.2136/sssaj1978.03615995004200030009x

[14] Australian and New Zealand Environment and Conservation Council (ANNZECC) 
and Agriculture and Resource Management Council of Australia and New Zealand (ARM-CANZ) (2000) Australian and New Zealand Guidelines for Fresh and Marine Water Quality. Australian and New Zealand Environment and Conservation Council and Agriculture and Resource Management Council of Australia and New Zealand, Canberra, Chapter 3, 1-103.

[15] Soil Survey Manual (1993) Soil Survey Division Staff, Soil Conservation Service. Handbook No. 18, U.S. Department of Agriculture, Washington DC.

[16] Tilley, N. (2021) Copper and Soil-How Copper Affects Plants. Soil, Fixes \& Fertilizers. Gardening-Know How.

https://www.gardeningknowhow.com/garden-how-to/soil-fertilizers/copper-for-the -garden.htm

[17] Rao, C.R.M., Sahuquillo, A. and Sanchez, J.F.L. (2008) A Review of the Different Methods Applied in Environmental Geochemistry For Single and Sequential Extraction of Trace Elements in Soils and Related Materials. Water, Air, and Soil Pollution, 189, 291-333. https://doi.org/10.1007/s11270-007-9564-0

[18] Mellum, H.K., Arnesen, A.K.M. and Singh, B.R. (1998) Extractability and Plant Uptake of Heavy Metals in Alum Shale Soils. Communications in Soil Science and Plant Analysis, 29, 1183-1198. https://doi.org/10.1080/00103629809370019

[19] Kashem, M.A. and Singh, B.R. (2004) Transformations in Solid Phase Species of Metals as Affected by Flooding and Organic Matter. Communications in Soil Science and Plant Analysis, 35, 1435-1456. https://doi.org/10.1081/CSS-120037556

[20] Gambrell, R.P. and Patrick, W.H. (1988) The Influence of Redox Potential on the Environmental Chemistry of Contaminants in Soils and Sediments. In: Hook, D. Ed., The Ecology and Management of Wetlands, Timber Press, Portland, 319-333.

[21] Haldar, M. and Mandal, L.N. (1979) Influence of Soil Moisture Regimes and Organic Matter Application on the Extractable $\mathrm{Zn}$ and $\mathrm{Cu}$ content in Rice Soils. Plant and Soil, 53, 203-213. https://doi.org/10.1007/BF02181891

[22] Leggett, G.E. and Argyle, D.P. (1983) The DTPA-Extractable Iron, Manganese, Copper, and Zinc from Neutral and Calcareous Soils Dried under Different Conditions. Soil Science Society of America Journal, 47, 518-522. https://doi.org/10.2136/sssaj1983.03615995004700030025x

[23] Shuman, L.M. (1980) Effects of Soil Temperature, Moisture and Airdrying on Extractable Manganese, Iron, Copper, and Zinc. Soil Science, 130, 336-343. https://doi.org/10.1097/00010694-198012000-00008

[24] Ure, A.M. and Davidson, C.M. (2001) Chemical Speciation in the Environment. Blackie, Glasgow, 464. https://doi.org/10.1002/9780470988312

[25] Khan, A. and Soltanpour, P.N. (1978) Effect of Wetting and Drying DTPA Extractable $\mathrm{Fe}, \mathrm{Zn}, \mathrm{Mn}$ and $\mathrm{Cu}$ in Soils. Communications in Soil Science and Plant Analysis, 9, 193-202. https://doi.org/10.1080/00103627809366800

[26] Tack, F.M.G. and Verloo, M.G. (1999) Single Extractions versus Sequential Extraction for the Estimation of Heavy Metal Fractions in Reduced and Oxidized Degraded Sediments. Chemical Speciation \& Bioavailability, 11, 43-50. https://doi.org/10.3184/095422999782775708

[27] Basta, N.T., Ryan, J.A. and Chaney, R.L. (2005) Trace Element Chemistry in Residual-Treated Soil: Key Concepts and Metal Bioavailability. Journal of Environmental Quality, 34, 49-63. https://doi.org/10.2134/jeq2005.0049dup 